\title{
The Impact of Tax Amnesty Announcement towards Share Performance and Market Reaction in Indonesia
}

\author{
Lidya Agustina ${ }^{1}$, Yuliana Gunawan ${ }^{1} \&$ Windawaty Chandra ${ }^{2}$ \\ ${ }^{1}$ Permanent Lecturer at Faculty of Economics Accounting Program of Maranatha Christian University, Jl. Prof. \\ Drg. Surya Sumantri No.65 Bandung 40164, Indonesia \\ ${ }^{2}$ Student at Faculty of Economics Accounting Program of Maranatha Christian University. \\ Correspondence: Lidya Agustina, Faculty of Economics Accounting Program of Maranatha Christian University, Jl. \\ Prof. Drg. Surya Sumantri No.65 Bandung 40164, Indonesia
}

Received: November 2, 2017

Accepted: January 16, $2018 \quad$ Online Published: January 16, 2018

doi:10.5430/afr.v7n2p39

URL: https://doi.org/10.5430/afr.v7n2p39

\begin{abstract}
The Indonesian Government reviewed back the tax amnesty in 2016. Various reactions came up along with the announcement of tax amnesty, the investors did not accept- which led to the announcement of the Tax Forgiveness regulation through the market reactions and stock market performances in Indonesia Stock Exchange. This research is to analyze event study using information based on government-related announcements to show the impact of the new regulation towards stock performance and market reaction. The effect of the announcement will be seen from the changes in stock-prices or stock-returns that provide abnormal returns in the event period as well as market reaction which reflected in trading volume. This research used stock-return data and trading volume from all companies listed in IDX in 2016 and analyzed using the Paired Sample T-Test method. The result of this research shows there are differences among the average of stock-return, average abnormal-return of stock, and stock trading volume before and after the tax amnesty announcement.
\end{abstract}

Keywords: Event study, Tax amnesty announcement, Stock performance, Market reaction

\section{Background of Research}

Capital market is a broad category of markets facilitating the buying and selling of financial instruments. It plays a big role for a country's economy it moves money from people who have it to organizations who need it in order to be productive. Investing is about putting money into stocks, bonds, mutual funds, or capital investment for one asset or more, which is usually for long-term, with the expectation of obtaining an additional income or profit. The development of the investment trend in Indonesia is reflected through the increase in stock-trading transactions that occurred in Indonesia Stock Exchange (IDX a.k.a BEI). It shows a positive impact of the economic improvement of Indonesia.

According to Malinda (2011:5), there are several factors that affect the success rate of capital market: (1) Supply of securities; (2) Demand of securities; (3) The political and economic conditions of a country; (4) Legal and regulatory issues; (5) The existence of institutions that organize and supervise transactions efficiently. Of all these factors, the most common phenomena in Indonesia are the political and economic conditions such as an establishment of a policy or law. This condition is one of the factors that can cause the capital market to react.

The Government of Indonesia once again reviewed the tax forgiveness law, or better known as tax amnesty.

There were some reasons for Indonesian Government to issue Tax Amnesty Policy: many tax payers had not reported their Capital Assets (either domestic or overseas) to their Annual Income Tax, to increase the national revenue as well as the economic growth, to trace the assets of Indonesian investors who invested their fund on illegal companies to avoid the tax as stated in Panama Papers case. Base on these reasons then On July 12016 , the Indonesian government announced the Act No.11 year 2016 about Tax Amnesty, which aims to fundamentally and thoroughly improve the macro-economic conditions in Indonesia. Tax amnesty provides an opportunity for tax payers, both individuals and entities, which have not yet fulfilled the tax obligation on their possessions to disclose their property, both domestically and abroad and to pay ransom money instead of the penalty. Tax payers who participate in tax amnesty will be freed from tax-administration and criminal penalties in the field of taxation. 
The purpose of tax amnesty among others: to accelerate and revamp economic growth by legal-assets-transfer which would impact to the increasing domestic liquidity and Indonesia's currency and decreasing rate of interest, and to encourage tax reform and to enlarge a more comprehensive, integrated and valid tax database.

Tax Amnesty has brought positive influence to the domestic stock market. The capital market surged as the guarantee for the massive fund flow caused by this new policy. Thus, foreign investors would also invest their fund in Indonesia, mainly though the stock market.

Various reactions emerged against the announcement of tax amnesty, not to mention the reactions of investors who responded to the announcement of tax amnesty through market reaction and stock market performance in Indonesia Stock Exchange. But in fact, when the Tax Amnesty Act was carried out on July 1, 2016, ICI (a.k.a. Indonesia Coal Index) was closed down by decrement of 45.07 points to $4,971.58$ from the previous closing points of 5,016.65. Likewise, it was recorded that the stock trading volume was decreased to 3.9 billion compared to the previous closing day which was 5.3 billion (www.idx.go.id).

The Changes in stock prices and stock trading volume in the stock exchange have become an important indicator for investors on transactions' decisions making in stock market. This happens because the investors tend to make transactions' decisions based on the information they get so the haveges in stock prices and trading volume are reflections of the information that investors believe. This research aims to analyze based on event study.

"Event study" is a study of market reaction towards an event which information is published as an announcement (Jogianto, 2010). The analysis of event study can be used to analyze the semi-strong form of the market efficiency. Jogianto (2010) explained that the market is said to be semi-strong efficient if the prices of securities have fully reflected the published information. The information mentioned may be such as earnings-related announcements, forecasting announcement by company's officials, dividend announcements, fund announcements, government-related announcements, investment announcements, employment announcements, law-related announcements, marketing-production-sales announcements, management-directors announcements, announcements of merger-take over-divestment, securities industry announcements, and etcetera.

Based on the information above, this research aims to analyze the event study by using the information based on government-related announcements to see the effect of the new regulations towards stock performance and market reaction. The existence of the effect from the announcement will be seen from the changes in stock prices or stock returns (stock performance) that provides an abnormal return in the event period.

Stock performance is an achievement measurement that can be accomplished by the company's stock management and reflects the company's health condition (Sudarsini, 2005). Therefore, stock return that shows the value of stock price changes in the market, and abnormal return that shows that the return is not normal, both of them is because of an event or announcement which is able to show the performance of stock. While the existence of an announcement related to the government's policy may lead to a surge in the number of outstanding shares in the community. This shows that an announcement may affect the market reaction, the more positive signal given from the announcement for the investors, the frequency of the transaction will also increase as the investors interest to the stock is also in high demand.

The previous research on event study that occurred in the public company's environment such as announcement of merger policy, right issue announcement, stock split, buy back, dividend payout, insider trading, and earnings announcement have often been done. However, research that analyzes the event study that occurs due to various regulations and economic deregulation issued by the government in Indonesia has not been much analyzed.

Previous researches that examined on event study related to economic events in Indonesia include the liquidation of 16 banks events in 1997, the announcement of the increase of fuel prices on April 1 2002, and the announcement of the approval of the Governor of Bank Indonesia on May 142003 (Manullang 2004). The results of previous researches showed a significant negative abnormal returns before and after the announcement of the delay of disbursement of IMF funds (Mahgianti, 2001), there are significant abnormal returns on 31 events (28 social political events and 23 economic events between 1996-2003), and IDX was in a semi strong efficient market condition (Manullang, 2004), then Zaqi (2006) proved that there is a market reaction towards the economic and social-political events that occurred in Indonesia. Therefore, based on the background that has been explained above, this research aims to analyze whether there are differences in stock returns, stock return abnormalities and stock trading volume of all companies that are listed at Indonesia Stock Exchange (ISE) in 2016 before and after the date-announcement of Tax Amnesty. The results of this research are expected to provide a new point of view or input for the investors in analyzing an announcement in decision-making for transactions in the stock market. 


\section{Hypothesis Development}

\subsection{Market Efficiency}

An efficient market concept is emphasized on the information aspect, which means that an efficient market is a market where the prices of all traded securities have reflected to all the available information, both past and present information, as well as information of opinion or rational opinion circulating in a market that may affect the stock price changes in the market (Tandelilin, 2010). The concept of market efficiency shows a process of adjusting stock prices so a new equilibrium is achieved as a form of market response to the existed information

Efficient market hypothesis emphasizes how fast new information is absorbed by the market as reflected in adjustments to the new equilibrium price (Tandelilin, 2010). Analyzing of event study can be used to analyze the semi strong form of the market efficiency (Jogianto, 2010).

Event study is a study which studies about market reaction towards an event which the information is published as an announcement (Jogianto, 2010). Event study is used to analyze the information content of an announcement, where good news will get a positive response by the market as reflected through market prices that will provide positive abnormal returns implications. As for bad news will give a bad market response which is reflected through market prices that will provide negative abnormal returns implications.

Hartono (2007) forecasted stock performance using stock return and daily abnormal stock return around the announcement date. Meanwhile, according to Ika and Purwaningsih (2008) market reaction can be shown by changes in stock prices, frequency of stock trading, and stock returns on the market. Therefore, events which have occurred that contain relevant information content to investors will cause a market reaction which is reflected through changes in stock prices. The results of previous research showed that there were differences between stock returns and abnormal returns before and after the occurrence of announcements or events (Mahgianti, 2001; Manullang, 2004; Zaqi, 2006; Sari, 2015). Based on the description above, the hypothesis can be formulated as follows:

$\mathrm{H1}=$ there is a difference of the average of stock return in IDX in 2016 before and after tax amnesty announcement

H2 = there is a difference of average abnormal return of company stock in IDX in 2016 before and after tax amnesty announcement

Market reaction can be reflected from the high interest of investors towards a stock, so if the stock is in a great demand, investors will try to get the stock as much as possible. Therefore, market reaction can be reflected from the level of stock trading volume. Changes in stock prices and stock trading volume on the stock exchange have become an important indicator for investors on transactions decisions making in the stock market. This happens because investors tend to make transactions based on the information they have. While the existence of an announcement that can cause a surge in the number of the outstanding shares in the community. This shows that an announcement may affect the market reaction, the more the positive signal is given from the announcement for the investors, and the frequency of the transaction will also increase as the interest of the investors towards stock is also high.

The results of previous research that analyzed the event study on political events in Indonesia towards market reaction which is represented by trading volume showed that the stock trading volume which contained significant differences in the period before and after political events were shown in Meidawati and Harimawan (2004), Wardhani (2013), and Sari (2015) research. Based on the description above, the hypothesis can be formulated as follows:

H3 = there is a difference of average stock trading volume in IDX in 2016 before and after tax amnesty announcement

\section{Research Methods}

This research is an event study that aims to observe the response towards an event. The data used in this research are stock price data and stock trading volume for all sectors of companies that are listed at Indonesia Stock Exchange in 2016 which were downloaded at www.idx.co.id with the following criteria:

a. Companies which are listed at IDX in 2016;

b. Companies which have issued the audited financial report of 2015 . 
Table 1. Operational Variable

\begin{tabular}{ll}
\hline Variable & Definition \\
The announcement & \\
Stock returns & A Return is a result of investment. \\
& The stock return could be indicated \\
from the realization return. The \\
realization return is a return that has \\
occurred which is calculated using \\
historical data. The realization return \\
is important because it is used as one \\
of the performance indicators of the \\
company and as a basis for \\
determining expected return to \\
measure the future risk (Jogianto, \\
2010).
\end{tabular}

Abnormal Return

Trading Activity
An Abnormal return is an excess of the actual return toward the normal return (Jogianto, 2010).

Volume

Stock trading volume is the number of stocks traded and being compared with the number of outstanding shares (Hartono, 2007).

\section{Note}

The announcement date means the date when the Indonesian government announced the tax amnesty policy, which is on July 01, 2016.

Stock returns or realization return can be calculated by deducting the closing price day-t with the closing price of day $(\mathrm{t}-1)$, then dividing it with the closing price of day (t-1).
As for the steps used to calculate abnormal return is as follows (Jogiyanto, 2010):

a. Calculate the expected return that will be calculated using a market-adjusted model.

$$
\mathrm{E}(\mathrm{Ri}, \mathrm{t})=\frac{\text { IHSGt }- \text { IHSGt }-1}{\text { IHSG } \mathrm{t}-1}
$$

b. Calculate the daily abnormal return of each stock during the event period by using the following calculation: $\mathrm{ARi}, \mathrm{t}=\mathrm{Ri}, \mathrm{t}-\mathrm{E}(\mathrm{Ri}, \mathrm{t})$

c. Calculate the Cumulative abnormal return (CAR) during the event period using the following calculation: $\quad \mathrm{CARi}, \mathrm{t}=\Sigma \mathrm{ARi}, \mathrm{t}$

Trading Volume Activity (TVA) is used as a measurement of stock trading volume to see if investors will respond positively or negatively towards an announcement.

\section{i Company stocks which are traded at t time}

$\mathrm{TVA}=\mathrm{i}$ Company outstanding shares (listing) at t time

The hypothesis of this research will be analyzed using a different test method from the previous research, which is Paired Sample T-Test, an analytical tool to analyze if there are any significant differences of the average of stock return and average abnormal return, and stock trading volume before and after the announcement. The reason of using Paired Sample T-Test method is because the data which tested are related one to another.

\section{Research Result}

\subsection{Result}

Based on the observation of 535 company's stocks in IDX in 2016 for 10 days before and 10 days after the announcement of Tax Amnesty, the information content around the announcement period can be explained through table 2 as follows: 
Table 2. Stock returns around the announcement of Tax Amnesty

\begin{tabular}{|c|c|c|c|c|c|c|}
\hline & \multicolumn{6}{|c|}{ Test Value $=0$} \\
\hline & \multirow[t]{2}{*}{$\mathrm{t}$} & \multirow[t]{2}{*}{ df } & \multirow[t]{2}{*}{$\begin{array}{l}\text { Sig. } \\
\text { (2-tailed) }\end{array}$} & \multirow[t]{2}{*}{ Mean Difference } & \multicolumn{2}{|c|}{$\begin{array}{l}95 \% \text { Confidence Interva } \\
\text { of the Difference }\end{array}$} \\
\hline & & & & & Lower & Upper \\
\hline RS_10 & 2,237 & 528 &, $026 * *$ & ,00275558 &, 0003358 & ,0051754 \\
\hline RS_9 & 3,792 & 528 &, $000 *$ & ,00520282 & ,0025075 & ,0078981 \\
\hline RS_8 & 2,700 & 528 &, $007 *$ & ,00382654 & ,0010428 & ,0066103 \\
\hline RS_7 & 1,072 & 528 &, 284 & ,00242966 &,- 0020207 & ,0068800 \\
\hline RS_6 & $-1,696$ & 528 & ,091 &,- 00317212 &,- 0068467 &, 0005025 \\
\hline RS_5 & $-5,542$ & 528 &, $000 *$ &,- 00630966 &,- 0085463 &,- 0040730 \\
\hline RS_4 & 1,392 & 528 & , 165 & ,00166189 &,- 0006843 & ,0040081 \\
\hline RS_3 & 2,040 & 528 &, $042 * *$ & ,00244117 & ,0000906 & ,0047917 \\
\hline RS_2 & 2,699 & 529 &, $007 *$ & ,00573832 & ,0015621 & 0099145 \\
\hline RS_1 & 2,201 & 530 &, $028 * *$ & ,00589021 & ,0006330 & ,0111474 \\
\hline RS0 & ,149 & 530 &, 882 & ,00023107 &,- 0028199 & ,0032821 \\
\hline $\mathrm{RA}+1$ & 5,770 & 528 &, $000^{*}$ & ,00962497 & 0063479 & ,0129021 \\
\hline $\mathrm{RA}+2$ & 2,369 & 528 &, $018 * *$ & ,00624681 & ,0010674 &, 0114263 \\
\hline $\mathrm{RA}+3$ & 2,425 & 528 &, $016 * *$ & ,00352647 & ,0006697 & ,0063832 \\
\hline $\mathrm{RA}+4$ &,- 370 & 528 &, 711 &,- 00073142 &,- 0046124 & ,0031496 \\
\hline $\mathrm{RA}+5$ & 2,565 & 528 &, $011 * *$ & ,00384905 & 0009009 & ,0067972 \\
\hline $\mathrm{RA}+6$ & 1,416 & 528 &, 157 & ,03358025 &,- 0130046 & ,0801651 \\
\hline $\mathrm{RA}+7$ & 1,448 & 528 &, 148 & ,05078798 &,- 0181090 & ,1196850 \\
\hline $\mathrm{RA}+8$ & 3,688 & 528 &, $000 *$ & ,00584017 & ,0027292 & ,0089511 \\
\hline $\mathrm{RA}+9$ &,- 770 & 528 & ,442 &,- 00115856 &,- 0041145 & ,0017974 \\
\hline $\mathrm{RA}+10$ &,- 349 & 528 &, 727 &,- 00043735 &,- 0028964 & ,0020216 \\
\hline
\end{tabular}

* Significant at $\alpha=1 \%$

Source: SPSS result

**significant at $\alpha=5 \%$

Based on table 2, it can be seen that before the date of the announcement of Tax amnesty (RS 0), the decline in stock return occurs only in the period of -6 and -5 which is indicated by a negative value. While in the period of -4 days before the announcement until the period of +3 days after the announcement, the stock return tends to increase which is indicated by a positive value, but stock return shows a great increment in the period of +1 after the announcement. Decrease in stock return again occurred after the announcement period which is in the period of +4 , then increased again and eventually decreased in the period of +9 and +10 again.

Based on the observations, it can be seen from table 1 that the announcement of Tax amnesty gives a positive signal for investors, it is shown from the stock return on the day of announcement and after announcement has increased. On the day of the announcement of Tax Amnesty, stock return showed the amount of 0.00023107, while on the day after the announcement of Tax amnesty, the stock return has increased to 0.00962497 . The increase in stock returns that occurred also shows that there is an occurrence of abnormal return in the period of Tax amnesty announcement. Table 2 shows observations towards abnormal returns for the periods before and after the date of the announcement.

Table 3 shows that there is a negative abnormal return in the period of -3 and -2 before the announcement, while the positive abnormal return occurred in the period of -1 , while on the announcement date, a negative abnormal return occurred. Furthermore, the positive abnormal return occurred in the period of +3 after the announcement date, but in the period of +7 , the negative abnormal return occurred again and afterwards in the period of +8 and +9 , the abnormal return was back to positive. 
Table 3. Abnormal returns around the announcement of Tax amnesty

\begin{tabular}{|c|c|c|c|c|c|c|}
\hline & \multicolumn{6}{|c|}{ Test Value $=0$} \\
\hline & \multirow[t]{2}{*}{$\mathrm{t}$} & \multirow[t]{2}{*}{ df } & \multirow[t]{2}{*}{ Sig. (2-tailed) } & \multirow[t]{2}{*}{$\begin{array}{l}\text { Mean } \\
\text { Difference }\end{array}$} & \multicolumn{2}{|c|}{$\begin{array}{l}\text { 95\% Confidence Interval of the } \\
\text { Difference }\end{array}$} \\
\hline & & & & & Lower & Upper \\
\hline AR_9 &,- 470 & 526 & ,638 &,- 0006478558 &,- 003353261 & ,002057550 \\
\hline AR_8 &, 506 & 526 & ,613 & ,0007201708 &,- 002074134 & ,003514475 \\
\hline AR_7 &,- 563 & 526 &, 574 &,- 0012800569 &,- 005747340 & ,003187226 \\
\hline AR_6 & ,755 & 526 & ,451 & 0014175901 &,- 002270988 & ,005106168 \\
\hline AR_5 & 1,591 & 526 &, 112 & ,0018180835 &,- 000426798 & ,004062965 \\
\hline AR_4 & 1,134 & 526 &, 257 & ,0013598292 &,- 000995260 & ,003714918 \\
\hline AR_3 & $-5,901$ & 526 &, $000 * *$ &,- 0070874953 &,- 009446903 &,- 004728087 \\
\hline AR_2 & $-6,701$ & 527 &, $000 * *$ &,- 0142998106 &,- 018491768 &,- 010107853 \\
\hline AR_1 & 5,910 & 528 &, $000 * *$ & ,0092139319 & ,006151371 & ,012276493 \\
\hline AR0 & $-5,979$ & 528 &, $000 * *$ &,- 0099744802 &,- 013251585 &,- 006697376 \\
\hline AR1 &, 086 & 528 & ,931 & ,0002269187 &,- 004952529 & ,005406367 \\
\hline AR2 & $-2,215$ & 528 &, $027 *$ &,- 0032206427 &,- 006077382 &,- 000363904 \\
\hline AR3 & 4,599 & 528 &, $000 * *$ & ,0090863894 & ,005205391 & ,012967388 \\
\hline AR4 &,- 927 & 528 &, 354 &,- 0013910397 &,- 004339216 & ,001557136 \\
\hline AR5 & 1,273 & 528 & ,204 & ,0301902647 &,- 016394626 & ,076775156 \\
\hline AR6 & 1,196 & 528 & ,232 & ,0419477127 &,- 026949288 & ,110844713 \\
\hline AR7 & $-4,856$ & 528 &, $000 * *$ &,- 0076903025 &,- 010801262 &,- 004579343 \\
\hline AR8 & 2,507 & 528 &, $012 * *$ & ,0037716446 & ,000815689 & ,006727600 \\
\hline AR9 & 2,671 & 528 &, $008^{* *}$ & ,0033428166 & ,000883815 & ,005801818 \\
\hline
\end{tabular}

* Significant at $\alpha=1 \%$

**Significant at $\alpha=5 \%$

\subsection{Hypothesis Test}

The hypothesis of this research is tested using Paired Sample T-Test to see if there are differences of two data groups, which are data before the date of the announcement and data after the date of the announcement.

The test result of Paired Sample T-Test on stock return data group before and after the Tax Amnesty announcement can be seen in table 4 and table 5 as follows:

Table 4. Average of stock returns

\begin{tabular}{llllll}
\hline & & Mean & N & Std. Deviation & Std. Error Mean \\
\hline Pair & RS_BF &, 00197104272 & 534 &, 011626681559 &, 000503135718 \\
1 & RS_AF &, 01100881264 & 534 &, 097388683919 &, 004214420526 \\
\hline
\end{tabular}


Table 5. Difference in average of stock returns test

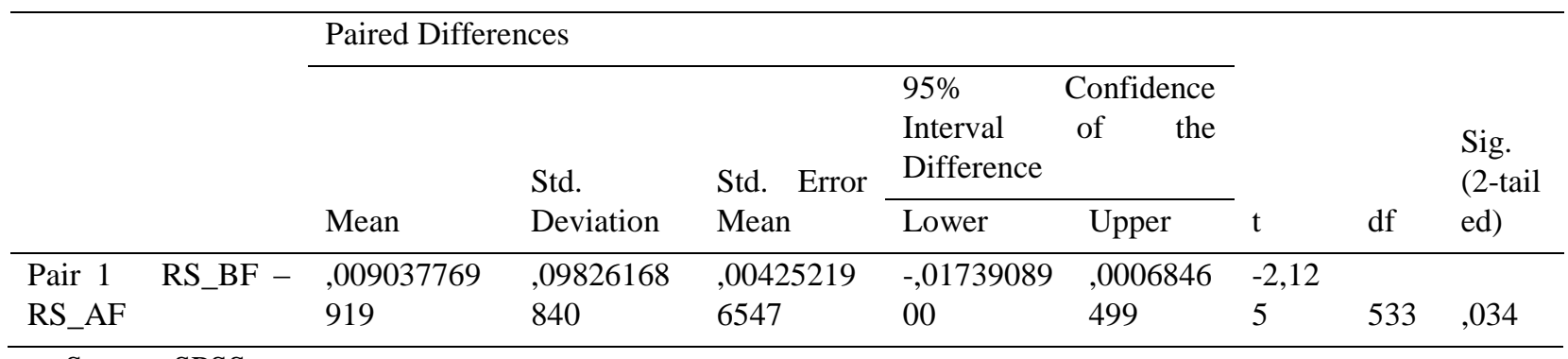

Source: SPSS

Table 4 shows that the average stock price after the announcement of tax amnesty has increased compared to the average of the previous stock price $(0.00197104272<0.01100881264)$, while table 5 shows that the difference of the average of stock price before and after the announcement date is significant (2-tailed) at the 5\% level by 0.034 . Thus, the first hypothesis is accepted or in other words there is a difference in average of stock returns before and after the date of tax amnesty announcement. The results of this research are in common with Mahgianti (2001), Manullang (2004), Zaqi (2006), Sari (2015), who found differences in stock returns and abnormal returns before and after the announcement or an event.

The test result of Paired Sample T-Test towards abnormal return data group before and after the date of tax amnesty announcement can be seen in table 6 and table 7 as follows:

Table 6. Average Abnormal returns

\begin{tabular}{llllll}
\hline & & Mean & N & Std. Deviation & Std. Error Mean \\
\hline Pair & AR_BF &,- 00081616481 & 532 &, 011646600980 &, 000504944191 \\
1 & AR_AF &, 00663434060 & 532 &, 097561329387 &, 004229820068
\end{tabular}

Table 7. Difference in Average abnormal returns test

\begin{tabular}{|c|c|c|c|c|c|c|c|c|c|}
\hline & & \multicolumn{5}{|c|}{ Paired Differences } & \multirow[b]{3}{*}{$\mathrm{t}$} & \multirow[b]{3}{*}{$\mathrm{df}$} & \multirow{3}{*}{$\begin{array}{l}\text { Sig. } \\
\text { (2-tail } \\
\text { ed) }\end{array}$} \\
\hline & & \multirow[b]{2}{*}{ Mean } & \multirow{2}{*}{$\begin{array}{l}\text { Std. } \\
\text { Deviation }\end{array}$} & \multirow{2}{*}{$\begin{array}{l}\text { Std. Error } \\
\text { Mean }\end{array}$} & \multicolumn{2}{|c|}{$\begin{array}{l}\text { 95\% Confidence Interval } \\
\text { of the Difference }\end{array}$} & & & \\
\hline & & & & & Lower & Upper & & & \\
\hline Pair 1 & AR_BF - & ,007450505 & ,09843977 & ,00426790 &,- 01583455 & ,00093354 & $-1,7$ & 53 & \\
\hline AR_AF & & 414 & 3174 & 5436 & 63 & 5424 & 46 & 1 & ,081 \\
\hline
\end{tabular}

Source: SPSS

Table 6 shows that the average abnormal returns after the date of tax amnesty announcement has increased compared to the average abnormal return before the announcement date $(0.00081616481<0.0066343406)$, while in table 7 shows that the occurrence of differences in average abnormal returns before and after the announcement date is significant (2-tailed) at the $10 \%$ level by 0.081 . Thus, the second hypothesis is accepted or in other words there is a difference in average abnormal return before and after the date of the announcement of Tax amnesty. The results of this research are in common with Mahgianti (2001), Manullang (2004), Zaqi (2006), Sari (2015), who found differences in stock returns and abnormal returns before and after the announcement or an event.

The test result of Paired Sample T-Test towards abnormal returns data group before and after the date of tax amnesty announcement can be seen in table 8 and table 9 as follows:

Tabel 8. Average of Trading Volume

\begin{tabular}{llllll}
\hline & & Mean & $\mathrm{N}$ & Std. Deviation & Std. Error Mean \\
\hline Pair & VOL_BF &, 00001820368 & 532 &, 000047814649 &, 000002073028 \\
1 & VOL_AF &, 00002423440 & 532 &, 000067768697 &, 000002938146 \\
\hline
\end{tabular}


Table 9. Difference average of trading volume test

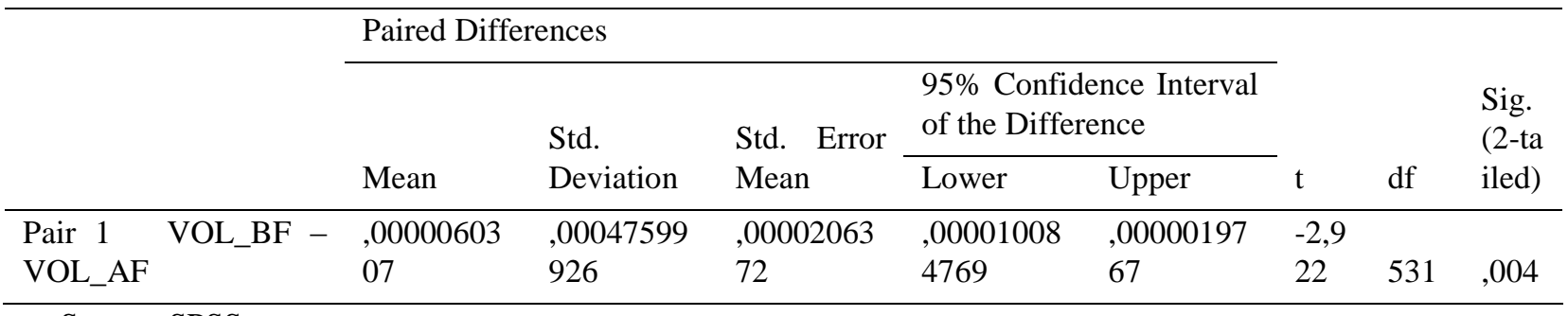

Source: SPSS

Table 8 shows that the average of stock trading volume after the date of the announcement of tax amnesty has increased compared to the average of stock trading volume before the announcement date $(0.00001820368$ $<0.0000242344$ ), while in table 9 , it is shown that the occurrence of difference in average of stock trading volume before and after the announcement date is significant (2-tailed) at the 5\% level by 0.004 . Thus, the third hypothesis is accepted or in other words there is a difference in average of stock trading volume before and after the date of the announcement of Tax amnesty. The results of this research are in common with the results of Meidawati and Harimawan (2004), Wardhani (2013), Sari (2015) research who found differences in stock trading volume before and after the announcement or an event.

\subsection{Discussion}

Based on the results described above, it can be proved that the announcement of Tax amnesty event has an impact towards market reaction which is reflected through stock return, abnormal return and stock trading volume. The stock return increases after the announcement date, as well as the abnormal return that becomes positive after the announcement date. This can prove that the semi-strong form market efficiency occurs in the Indonesia capital market, for the sample of all sectors of industries from companies that are listed at ISE in 2016, where the published information or events can affect the price of securities around the announcement period.

\section{Conclusion \& Suggestion}

\subsection{Conclusion}

Based on the results above, we can conclude that:

1. There is a difference between the average of stock returns before and after the date of tax amnesty announcement. Average of stock returns has increased after the date of the Tax amnesty announcement. This means that this tax forgiveness news gives a significant impact towards capital market.

2. There is a difference between the average abnormal returns before and after the date of tax amnesty announcement. Average abnormal returns have increased after the date of the announcement of Tax amnesty. This means that there is a significant impact because of this tax forgiveness news.

3. There is a difference between the average of stock trading volume before and after the date of the Tax amnesty announcement. Average of stock trading volume has increased after the date of the announcement of Tax amnesty. This also means that this tax forgiveness news give a significant impact towards capital market's conditions.

\subsection{Suggestion}

Future research on event study may utilize information for investors on any events which provide implication towards market reaction, so, the next researcher can summarize various events which will have or will not have impacts towards market reaction, and also may consider other measures or variables rather that the three measures used in this study. Additional research might also be directed towards determination of the effect of tax forgiveness law announcement using larger samples or longer time series. Furthermore, the next researcher may use any other methods which are different from the methods used in this research.

\section{References}

Asmorojati, Wendi, dkk. (2016). "Reaksi Investor Terhadap Pengumuman Kebijakan Tax Amnesty Pada Tanggal 1 Juli 2016". e-Jurnal Ilmiah Riset Akuntansi.

Hartono. (2007). "Pengaruh Pengumuman Right Issue Terhadap Kinerja Saham dan Likuiditas Saham di Bursa Efek Indonesia”. Universitas Sebelas Maret. Surakarta.

http://idx.go.id 
http://www.Bisnis.com Tax Amnesty disahkan: IHSG \& Rupiah Melambung, Saham Ini Bakal Diuntungkan. Diunduh pada Jumat 16 September 2016.

Jogianto Hartono. (2010). Teori Portofolio dan Analisis Investasi. Edisi Ketujuh. Yogyakarta: BPFE.

Mahgianti, Rini. (2001). "Perilaku Harga dan Volume Perdagangan (Studi Peristiwa Dampak Penundaan Pencairan Bantuan IMF pada Saham Dominasi Asing dengan Pendekatan Koreksi Beta)", Proceeding Simposium Nasional Akuntansi IV, hal.956-995.

Manullang, Timbul Laurence Adolf. (2004). “Analisis Efisiensi Pasar Modal Indonesia Menggunakan Pendekatan Multiple Event Sosial \& Politik dan Ekonomi”, DesertasiProgram Doktor Ilmu Ekonomi Universitas Persada Indonesia YAI, Jakarta.

Mardiyah, A. A. dan Najib, A. (2005). "Perbedaan Publikasi Laporan Keuangan terhadap Volume Perdagangan Saham di Bursa Efek Jakarta”. Simposium Riset Ekonomi II, Ikatan Sarjana Ekonomi Indonesia.

Meidawati, Neni dan Harimawan, Mahendra. (2004). "Pengaruh Pemilihan Umum Legislatif Indonesia Tahun 2004 Terhadap Return Saham dan Volume Perdagangan Saham LQ-45 di PT. Bursa Efek Jakarta (BEJ)”. Sinergi, Vol. 7 No. 1, hal 89-101.

Mochamad Zaqi. (2006). "Reaksi Pasar Modal Indonesia Terhadap Peristiwa-Peristiwa Ekonomi dan Peristiwa-Peristiwa Sosial Politik Dalam Negeri (Studi Pada Saham LQ 45 Periode 1999-2003)”. Tesis Program Pascasarjana Universitas Diponegoro Semarang.

Sari, Putri Novita. (2015). "Pengaruh Pengumuman Kabinet Kerja Joko Widodo terhadap Perubahan Reaksi Pasar Modal pada Perusahaan Manufaktur di Bursa Efek Indonesia". Skripsi Jurusan Akutansi FEB Universitas Muhammadiyah Surakarta.

Satria, R dan Supatmi. (2013). "Reaksi Pasar Sebelum dan Sesudah Internet Financial Reporting". Jurnal Akuntansi dan Keuangan, Vol.15 No.2. hal.86-94. https://doi.org/10.9744/jak.15.2.86-94

Sudarsini. (2005). “Analisis Kinerja Jangka Pendek dan Jangka Panjang Perusahaan yang Melakukan Merger dan Akuisisi”. Skripsi. FE UNS.

Suyanto, dkk. (2016). “Tax Amnesty”. Jurnal Akuntansi. Fakultas Ekonomi: Universitas Sarjanawiyata Tamansiswa.

Tandelilin, E. (2010). Portfolio dan Investasi: Teori dan Aplikasi. Edisi pertama. Yogyakarta: Penerbit Kanisius.

Undang-Undang Republik Indonesia No.11. Tahun. (2016). Tentang Pengampunan Pajak.

Wulandari, I Gusti Agung A., dkk. (2017). "Reaksi Investor dalam Pasar Modal UU Tax Amnesty". Jurnal Akuntansi S1 Akuntansi. Universitas Pendidikan Ganesha. 